\title{
ANOTASI BIBLIOGRAFI \\ KEARIFAN LOKAL DALAM PEMBELAJARAN SEJARAH \\ DI MASA PANDEMI
}

\author{
Oleh \\ Jamaludin \\ Email: 1710111210009@mhs.ulm.ac.id \\ Program Studi Pendidikan Sejarah Fakultas Keguruan dan Ilmu Pendidikan \\ Universitas Lambung Mangkurat \\ Banjarmasin
}

Rochgiyanti, Susanto, H., (2018). "Tradisi Pemeliharaan Kerbau Kalang di Wilayah Lahan Basah Desa Tabatan Baru, Kecamatan Kuripan, Kabupaten Barito Kuala". Prosiding Seminar Nasional Lingkungan Lahan Basah, 3(2), 515-519.

Artikel ini merupakan hasil penelitian terkait kearifan lokal lahan basah yang membahas tentang pengelolaan kerbau kalang di Desa Tabatan Baru, Kecamatan Kuripan, Kabupaten Barito Kuala. Di bagian awal membahas terkait keadaan lahan basah di Kalimantan Selatan. Kemudian penulis menyampaikan penggunaan metode kualitatif dalam penelitian ini, selain itu observasi dan wawancara juga dilakukan untuk mendapatkan lebih banyak informasi, dan di bagian utama, pembahasan mencakup sistem pemeliharaan kerbau rawa, sistem bagi hasil \& pengupahan dan sistem penjualan kerbau rawa.

Abbas E. W., Winarso H. P., Meilina N., (2019). "Religious Activities At Sultan Adam Suriansyah Mosque, Banjarmasin”. 1(1), 55-63.

Atikel ini mengkaji tentang kegiatan atau aktivitas keagamaan yang dilaksanakan di Masjid Suriansyah. Masjid Sultan Suriansyah sendiri bisa dikatakan sebagai gerbang masuknya islam ke kawasan banjar. Penelitian dalam artikel ini menggunakan pendekata kualitatif dengan observasi, wawancara dan dokumentasi sebagai cara untuk mengumpulkan data. Unutk menguji keabsahan datanya digunakan triangulasi teknik. Dalam artikel ini dijelaskan dengan jelas bagaimana kegiatan yang dilaksanakn disana, mulai dari kegiatan harian, mingguan, bulanan, maupun dalam kurun periode tertentu. Dalam artikel ini kita bisa menyimpulkan bahwa Masjid Sultan Suriansyah merupakan salah satu pusat kegiatan keagamaan di Banjarmasin. 
Asmi A. R., (2018). Media Pembelajaran dalam Internalisasi Nilai-Nilai Kearifan Lokal Berbasis VCT (Value Clarification Technique) Pada Pembelajaran Sejarah". Jurnal Candrasangkala, Vol. 4, No. 1, Hal. 1-13, (2018).

Artikel ini mengkaji tentang analisis konseptual kolaborasi antara media pembelajaran dan VCT dalam pembelajaran yang dapat memberikan gambaran nilai-nilai yang ada pada kearifan lokal yang ada. Pembahasan yang mendalam terkait pemanfaatan teknologi dalam pembelajaran seperti handphone, laptop, tablet, dan lainnya. Di bagian akhir penulis menyampaikan kebijakan pembatasan penggunaan handphone di lingkungan sekolah yang menjadi permasalahan penerapan teknologi dalam pembelajaran sejarah. Asmi A. R. menyampaikan perlu adanya pengelolaan untuk mengambil sisi positif dengan memberdayaan perangkat mobile sebagai pendukung pembelajaran.

Susanto, H. (2019). Media Pembelajaran Sejarah Era Teknologi Informasi (Konsep Dasar, Prinsip, Aplikatif, dan Perancagannya). FKIP Universitas Lambung Mangkurat.

Buku yang memiliki total 138 halaman ini membahas tentang salah satu upaya untuk menciptakan pengalaman baru dalam pembelajaran sejarah menggunakan Aplikasi Pembelajaran berbasis smartphone. Dalam buku ini, penulis membagi materi menjadi dua bagian, yaitu Bagian Pertama adalah Pendahuluan, yang membahas tentang rencana pembelajaran, petunjuk penggunaan buku, sampai dengan bentuk evaluasi. Dan bagian kedua yaitu isi, pembahasan pada bagian kedua ini mencakup konsep dasar media pembelajaran sejarah, prinsip aplikatif pembuatan media sampai dengan perancangan media pembelajaran sejarah. Pembahasan dalam buku cukup bagus, terlebih lagi penulis menyertakan beberapa gambar dalam penyampaian materi yang mampu mempermudah pembaca dalam memahami buku ini.

Mutiani, et. al. (2020). Membangun Komunitas Belajar Melalui Lesson Study Model Transcript Based Learning Analysis (TBLA) dalam Pembelajaran Sejarah. Historia: Jurnal Pendidik dan Peneliti Sejarah, 3 (2), 113-122.

Artikel ini mengkaji terkait inovasi dalam pembelajaran sejarah, khususnya dalam menjawab permasalahan klasik dalam proses pembelajaran yaitu kurangnya partisipasi peserta didik. Pembahasan berfokus pada model TBLA, penulis meyakini bahwa model tersebut mampu memecahkan permasalahan klasik tersebut. Dalam penelitian ini digunakan pendekatan kualitatif dengan metode deskriptif. Untuk mendapatkan keabsahan data, peneliti menggunakan teknik triangulasi. Dan di akhir bagian, peneliti dapat menyimpulkan bahwa terdapat peningkatan kualitas pembelajaran yang mengindikasikan kemampuan berfikir historis peserta didik. 
Absor, N. F., (2020). Pembelajaran Sejarah Abad 21: Tantangan dan Peluang dalam Menghadapi Pandemi Covid-19. Chronologia: Journal of History Education, 2,(1), 3035

Artikel ini mengkaji tentang tantangan yang harus dihadapi oleh tenaga pendidik dalam melaksanakan pembelajaran dimasa pandemic Covid-19. Pembahasan dalam artikel ini menitikberatkan pada pemanfaatan media digital dalam pembelajaran sejarah. ide yang dikembangkan dalam tulisan ini juga menarik karena mampu menyajikan kajian yang relevan dengan keadaan saat ini. Menurut Absor, N. F. peraturan pemerintah yang mengharuskan pembelajaran dilaksanakan secara daring cukup menjadi momok bagi sebagian tenaga pendidik khususnya tenaga pengajar yang tidak terbiasa menggunakan teknologi. namun begitu tenaga pendidik tetap dapat melaksanakan pembelajaran sejarah menggunakan berbagai media daring seperti whatsapp, classroom, zoom meetng, google meet, youtube dan lainlain. Pada bagian akhir, penulis menyajikan berbagai hal yang dapat dilakukan saat menjalani tantangan dan peluang dalam menghadapi pandemic Covid-19.

\section{Kearifan Lokal Dalam Pembelajaran Sejarah dimasa Pandemi}

Kearifan Lokal merupakan suatu identitas budaya kelompok tertentu yang berjalan dan berkembang sesuai dengan watak dan kepribadian suatu kelompok yang pada umumnya memiliki filosofi nilai-nilai, cara-cara, mapun etika, Identitas budaya tersebut biasanya dapat bertahan dalam waktu yang lama. Kearifan lokal sendiri dipengaruhi oleh berbagai factor, beberapa diantaranya yaitu letak georafis, etnis, kepercayaan serta perilaku masyarakat itu sendiri.

Pembelajaran sejarah merupakan sebuah studi umumnya menjelaskan tentang budaya atau kegiatan manusia pada masa lampau, aspek yang dibahas sangat luas, mulai dari aspek kehidupan politik, hukum, geografis, sosial, ekonomi, kepercayaan, kebuadayaan, dan lain sebagainya. Ada banyak tujuan dari dilaksanakannya pembelajaran sejarah, khususnya bagi peserta didik di sekolah, beberapa diantaranya yaitu untuk meningkatkan rasa cinta tanah air kita terhadap negara, kemudian kita bisa membuat perencanaan kehidupan untuk dimasa depan dengan mempelajari sejarah. Walaupun stigma pembelajaran sejarah itu membosankan karena selalu berkutat dengan hafalan materi, namun sejatinya pembelajaran sejarah dapat dilaksanakan dengan menyenangkan. Terlebih lagi di era teknologi seperti ini, kita bisa memanfaatkan teknologi dalam pembelajaran seperti menampilkan video, penggunaan aplikasi berbasis smartphone, dan lain sebagainya.

Pandemi covid-19 menjadi tantangan sendiri bagi dunia pendidikan, dimana dengan adanya peraturan pemerintah terkait pembelajaran yang harus dilaksanakan secara daring membuat tenaga pengajar yang tidak terbiasa dengan teknologi menjadi khawatir, sehingga dengan pandemi ini kita dipaksa untuk lebih dekat dan akrab dengan teknologi dalam pembelajaran seperti penggunaan media sosial untuk sharing materi, platform video meeting seperti zoom dan google meet untuk menjelaskan materi, dan lain sebagainya. 